significant influence on the way the literary language of the new type came into being.

\title{
6. The Secularization of Culture, Its Specifics in Russia, and Its Significance for Rethinking Linguistic Usage
}

The process of cultural secularization was begun in Europe during the Renaissance, not because there was no secular culture before the Renaissance, but because until that time it had not presumed an independent role. This was a revolutionary moment, although it had organic roots in the past, first of all in the system of secular education that medieval Europe inherited from the Roman Empire; however weak this may have become, and however much an accessory to religious education, it remained capable of regeneration, and became organic soil for secularization. The Renaissance's continuity in this area was clearly marked, for example, in the character of its assimilation of the classical rhetorical tradition and of classical mythology (see Seznec 1961; Zhivov and Uspenskii 1984). A particular instance of this continuity is the fact that secular culture was by no means alien to connections with the Latin linguistic tradition; in this respect it wasn't opposed to religious culture. For this reason the process of secularization did not have a direct connection to the question of language. Secularization, of course, could serve as one of the factors influencing the redistribution of spheres of usage between Latin and the new national literary tongues, but the conception of a particular subject as specifically religious or secular by no means predetermined the language in which that subject was described. The democratizing of education significantly influenced the new distribution, but at least up to the eighteenth century democratization was more characteristic of religious than secular culture.

The starting points for the Eastern Slavs as a whole and Muscovite Rus' in particular were completely different. Here secular culture had no organic roots at all, and in this Russia differed not only from the West, but also from Byzantium. The issue then was not the specifics of Eastern Christianity, as is sometimes asserted (e.g. Trubetskoi 1973, 19-28), but in the special nature of the reception of Christian culture by the Eastern Slavs. It would be a mistaken exaggeration to assert that all spiritual interests of medieval Russian society were exclusively religious, that the life of the court or the patrimony of a boyar were but light-weight versions of monastic 
customs, and that rituals sanctioned by the church consumed all spiritual interests beyond its pale. Nevertheless, no institutionalized forms of secular culture existed in medieval Rus'. Here, unlike Byzantium, there was no tradition of secular education stretching back uninterruptedly to ancient times, there were no universities with schools of law and medicine, as in Western Europe, there were no juridical corporations, and, finally, there was no tradition of chivalric love and the literary and social practices connected with it. Those little beginnings of secular culture that researchers have sought out, and that were peripheral phenomena relative to the main lines of cultural development (like the "Song of Igor's Campaign," for example), may only be interpreted as such with significant qualifications, and though they may somewhat spoil the clarity of the historical picture, and make it impossible to speak in unambiguous structuralist terms, they nevertheless provide no basis for speaking of a special tradition; if there were such sprouts, they produced no fruit.

With this in mind, there are no grounds to speak of the secular culture of Kievan or Muscovite Russia, as is often done. It is unjustified to consider the chronicles as monuments of secular literature, and the same goes for the so-called military tales. One can certainly examine various lines of literary continuity from monument to monument, but these do not form any kind of special secular tradition. Most indicative in this case is the fact that during the entire medieval period there was an unceasing exchange of textual material and narrative models among works of religious literature and those monuments which from a modern point of view may be called secular (for example, between chronicles and hagiographical works). Unlike Byzantine or West European literatures, there were no boundaries between genres that could be seen to correspond to such differentiation of cultural traditions, and this absence of rhetorical organization is connected with the fact that in the last analysis the fundamental text that served as the standard for all written works without regard for their individual features was Holy Writ. The presence of this single supra-model relativizes the significance of isolated individual models that may form textual groups. As R. Picchio writes, "Imitation of the Bible resulted in a structural conception of each literary work as a component of a larger whole" (Picchio 1973, 447). As stated, this situation affected the development of the literary language in a fundamental way, insofar as its registers were not separated from each other by any kind of fixed border. For all of the importance of the religious tradition in Byzantium, no such single supra-model existed there. As I. Shevchenko remarks, "In Christian Byzantium the Scriptures never became a predominant model of style at any level, except, and there rarely, for the 
lowest forms of hagiography" (Shevchenko 1981, 209). To some extent this also applies to the medieval period in Western Europe, where the imitation of classical authors remained a required part of rhetoric. Considering these profound differences, the process of secularization, for all its universal importance in creating modern society, could not have proceeded in Russia according to that well-studied scheme that we observe in Western Europe.

In Russia, secular culture as an autonomous phenomenon only declared its existence in the seventeenth century. Whether this was because of typologically universal social processes on the cusp of the new era, or whether it was due to such special circumstances as contact with Polish court practices during the reign of the False Dmitri, need not concern us here. More crucial is the fact that new forms of cultural exchange come into being in the first half of the century, forms like the writing of poetry, so important for cultural self-identity. Insofar as (as we have argued) there was no basis for secular culture in Russia, its place was taken by imported elements. Before original secular tales like the Tale of Savva Grudtsyn or Frol Skobeev appeared, translated chivalric novels had to be circulated, and it was just such borrowed productions that formed the kernel of a secular tradition, at first quite restricted. However limited it was in terms of its content and in terms of its audience, it acquired a certain autonomy, and it is this that signals its most important innovation. In the 1630's polemic tract "On the Visible Image Of God," Ivan Begichev accuses his opponents of theological ignorance, and declares that they are familiar not with religious works but with "incredible tales" (basnoslovnye povesti), among which he names "the one about Bova Korolevich [prince Bovain]"; he thus makes the opposition between religious and secular literary traditions very clear [...] (Begichev 1898, 4).

As soon as a kernel of secular culture is formed, it begins to accumulate new material, not necessarily taken from without. Choices begin to become available, as older texts or other cultural artifacts are reconceptualized to fit new models and are included into paradigms to which they had no relation earlier. Thus the chronicles could now be taken as a simple telling of past events that could be regarded as parallel to western historical works and taken as part of a common secular tradition. For example, Andrei Lyzlov's Scythian History, written in the last decade of the seventeenth century, is a combination of fragments taken from various borrowed sources which taken together form a fully secular narrative, with no religious underpinning. Notably, Lyzlov defined his sources as "history books," including in their number as equals The Book of Degrees (Stepennaia kniga) and old Russian chronographs, on the one hand, and the histories of Baronius, Pliny, Martin Kromer and Alexander Guanini on the other (Lyzlov 1990, 7). 
However significant these accumulations, the kernel itself remained borrowed, and this determined the main semiotic characteristics of the new secular tradition. At its origin lay the mechanism by which heterogeneous cultures act on each other, stimulated by the change of context, that is, the mechanism of inadequate translation from one language to another, whose very inadequacy fuels creative development (see Lotman, I, 34-5; Klein 1990). Cultural borrowing, including the secularizing and Europeanizing of Russian culture in the seventeenth and eighteenth centuries, is expressed first of all in the assimilation of a series of external forms of behavior, daily life, literature, etc. These external elements play a historically defined role in the donating culture's cultural paradigm; they conform to a given set of values, life style, and way of thinking, and are that culture's organic expression. On transplantation into foreign soil, they lose their context, and, liberated from their original content, assume a heretofore nonexistent creative power; from external forms of expression they become generators of content.

Thus in Europe the German clothing which Peter I made state servitors assume there only fulfilled the simple function of clothing - to cover nakedness, defend from frost and heat, and adorn the wearer in accordance with his or her notions of elegance and fashion. However, transferred to Russia, a German caftan became an engine for enlightenment and an incarnation of Petrine absolutism, acquired didactic significance and as a symbol of the new culture served to differentiate the enlightened from those sunk in ignorance, the adherents of the past from the voluntary or involuntary supporters of change. State institutions and literary genres, philosophical doctrines and aesthetic conceptions all functioned in this same way. When we discover, for example, that Feofan Prokopovich's Rhetoric was almost completely based on analogous European moderate Baroque treatises (those of Nicolaus Caussinus and Melchior Junius — Lachmann 1982; Kibal'nik 1983), we naturally want to place it in this same series and to ascribe to it the same functions as its European models. The similarity, however, is deceptive. In Europe rhetorical manuals regulated already existing oral practice, helping the reader to combine certain rhetorical strategies with available rhetorical means. But in Russia the very same manual created new practices, and prescribed rather than recommended how to perform on occasions analogous to those in Europe. For all the external similarity of the rules, they took on a different meaning, and rhetoric turned into rules that governed the entire range of socially significant behavior ("Decorum-Rhetorik" as R. Lachmann calls them; Lachman 1982, lxi ff; Zhivov 1985a).

This metamorphosis of secular discourse was not very apparent in the seventeenth century insofar as secular culture was limited to a very small 
and rather closed social group. Practically it did not extend father than the court, and moreover was meant for internal consumption. At the court of Aleksei Mikhailovich a theater was set up, but only those close to the person of the tsar attended, and these innovations were not evidently perceived as a cultural reform but only as just another change in court life, bringing things up to date with other European court practices. And insofar as even earlier the inner life of the court stood somewhat apart in the cultural tradition, the tension between traditional and Europeanized culture was of limited, isolated importance. The supreme power reserved this culture for itself and did not try and spread it among its subjects, so that the cultural conflict and clash of paradigms it stimulated only existed in embryonic form and did not affect the main cultural categories. That which began to percolate out of palace halls could provoke negative reactions, but these were fully subsumed into religious discourse, related for example to the schism in the church, that is, a conflict between religious movements and not between secular and religious culture. ${ }^{19}$

In the Petrine epoch this esoteric culture went out into the streets. This is especially evident in what happened with that very same theater. As E. V. Petukhov writes $(1916,375)$, "From the very start, Peter looked at the theater not as a court amusement but as a social issue. The Boyar F. A. Golovin was commanded by the tsar to build "a hall for comedy" (komediinaia khoromina) on Red Square, right by the Kremlin, and it is quite typical that this order was opposed by the clerks of the foreign office, who found this a very questionable enterprise; however the hall was completed in December, and by Yule 1702-03 performances had probably already begun." Having become public, secular culture took on a completely new role: it no longer entertained the few but now educated society as a whole, or at least, that part of society that came within the grasp of the authority's new cultural paradigm. Assimilation of the new secular discourse became a criterion of loyalty $(\S$ I-1), and this was a basic change. Insofar as assimilating the new discourse became a life problem, people occupied in completely different spheres of activity began to adapt this imposed language to their own situatians, habits, and preexisting notions. This adaptation brought into play the mechanism of transformation that brought new content to the adopted forms of European

19 There exist several testimonies of how Old Believers perceived the theatrical presentations at the court of Aleksei Mikhailovich. [...] (Bubnov and Demkova 1981, 143). They were seen as a sign that the tsar had lost his faith and were considered of a piece with his innovations in church ritual. One can find this view in Avvakum's own Book of Interpretations and Admonitions (RIB, XXXIX, col. 466) and in his "Advice to the Sainted Holy Fathers" (Avvakum 1960, 255). 
culture described earlier. This was particularly complex and confused due to the fact that from the very start of its public existence the new system of values was sharply antagonistic toward traditional culture, which made it impossible to reconcile the old and new directly and openly and led to multiple ambiguities.

It is within the framework of this new value system that the Russian literary language of the new type was created, cutting all ties - at least in theory - with the entire previous written tradition. This new literary language was part of the new secular culture, and therefore the struggle for its dominance became an element of state policy that asserted the undivided authority of secular power. Thus from the very start, Russia's historical, cultural and linguistic development, inspired by Europeanization, gave rise to phenomena quite far from those European models on which it was oriented. One may say that imitation and borrowing took place only on an external level. The Europeanization of Russian culture turns out to be not so much a transfer as much as a reconceptualizing of European models, during the course of which the basic structures and categories of European thought acquired different meanings. The process of borrowing formed but a superficial layer; an examination of the actual functioning of the cultural system, and of those cultural conflicts that arose during that functioning, demonstrates what a profound transformation borrowed phenomena undergo, and in what complex relations they engage with traditional culture.

This transformation was manifested most significantly in the change in linguistic consciousness. In Peter's cultural program, what was European was perceived as new and progressive, and his cultural reforms aimed to introduce them onto Russian soil. One result of this program was the literary language of the new type. From the start, however, this result radically differed from its European correlatives. The differences were embedded in their very connection to the cultural politics of secularization. The opposing of the traditional written language and a literary language of the new type (the "simple language" of the Petrine era) was directly linked with the contrast between traditional versus secular cultures; and this connection was a specific peculiarity of the Russian linguistic situation that had no parallel in Europe. This connection also conditioned many special features of the new literary language that had an important influence on its development. If the notion of "simplicity" lay at the origin of the new language, then during its formation it became secondary to another cultural imperative, opposition to the traditional written language. This imperative derived from the correlation between the formation of the new language and the new system of values. The new literary language became a sign of the new secular culture, and this 
semiotic imperative defined both its structural characteristics as well as its functioning.

Thus secularization, in creating the possibility of a radical break with the Church Slavonic written tradition and a realization of the notion of a "simple tongue," at the same time led to the formation of a literary language for which the idea of simplicity had only secondary importance, while the main requirement was the connection to the new secular culture (§ I-2.2). While this connection retained its force the new literary language could not acquire polyfunctionality, a basic attribute of European literary languages ( $\S$ III-1.1). Limited in its functional sphere, it could not embody and impose on society the principle of the undivided authority of secular power, which was after all a basic reason for its creation. Because of this the broadening of the new language's functions combined with the problem of asserting the new imperial discourse and reflected all of those equivocations by means of which the Russian autocracy assumed the guise of enlightened absolutism, striving for the general good ( $(\mathrm{IV}-1)$.

No less paradoxical and far from European models was the new literary language's pretension to universality. The estate and caste stratification of society, strengthened by the Petrine reforms and restricting social mobility to an extreme, insofar as this was within the power of the not especially numerous and poorly educated bureaucracy, led not only to the growth of social tensions but to unprecedented cultural divisions within society. Various social groups assimilated (or failed to assimilate at all) the reigning Europeanized culture in various ways, and were loyal to traditional culture in varying degrees, so that each developed its own cultural language which was passed down to its children (insofar as children almost always inherited the profession and social status of their parents). Together with this inherited language children remained isolated from the values and views of other social groups, a lack of understanding that in time became an established tradition and social norm. As Isabella de Madariaga comments, "with the introduction of Western secular ideas, the different classes lived at a different tempo, according to how much or how little of the new ways they adopted, and the unifying principle was greatly weakened" (Madariaga 1982,111).

In different social groups different sets of texts had currency, and in different ways combined elements from a corpus including traditional religious texts, translated entertainment literature (like Bova or Peter of the Golden Keys), as well as the new Europeanized literature (cf. Rothe 1984). Because of this different social groups had different linguistic experiences that they related to their own cultural principles and transformed into new practices that in turn defined the language of texts they themselves created. One 
mission of the new literary language was to be universally comprehensible, but in practice its formation led to a new differentiation of written traditions that in addition took on a socially motivated character. If we can permit a simplified illustration, one might say that while an Old Believer continued to read the "Prologue" and write in hybrid Church Slavonic, an archimandrite of the church might imitate Prokopovich's rhetoric, a clerk could read Bova and write tales like the "History of Korolevich Arkhilabon" (cf. Sipovskii 1905; Berkov 1949), while a Sumarokov or Kheraskov would browse French and German journals, understanding at the same time that "the people can't understand my creations" - and each one of them scorning, and in part even hating, the others. In this way the universalism of the new language turned into a fiction, and its penetration into society functioned together with the propagation of the other political and cultural fictions that was a major component of government policy in eighteenth century Russia.

In light of these factors, the analysis of "language and culture" in Russia during this period is justified not only by the existence of a symbolic level in the language, a universal factor in all languages, but due to the special intensity of its formation, transformation, and dissemination into cultural consciousness. Language not only responded to and recorded in itself the stages of cultural evolution, but also served as one of the principle means of inculcating the reigning culture, and as such became one of the main elements of government policy. The establishment of the new type of literary language and its acquisition of the above-mentioned characteristics (polyfunctionalism, universal comprehensibility, codification, and differentiation of stylistic means) took place in direct and unusually expressive connection with the assertion of new cultural, religious, and political values, so that the development of the language serves not only as a mirror but as a magnifying glass, allowing us to view all of the complexity and contradictions in the genesis of modern Russian culture. 